\title{
Ambitious Japanese proposals for superconductors
}

Tokyo

JAPAN's Science and Technology Agency and Ministry of International Trade and Industry (MITI) have floated some ambitious proposals to promote research and development of high-temperature superconductors. But whether their plans will be realized will depend on negotiations with the Ministry of Finance and with industry over the coming months.

There is a widely held view in the West that Japan has already begun a coordinated national research effort to conquer the world market in high-temperature superconductors (if and when they reach the market). Such a view belies the fact that, despite a massive trade surplus, the Japanese government is up to its neck in debt, and any government agency or ministry has to fight tooth and nail to win funds for new research by going through a long application process that begins in the summer and ends in the new year when the budget for the following fiscal year is announced (and even then the budget is subject to Diet approval).

MITI, the Science and Technology Agency and the Ministry of Education,

\section{Last ditch attempt to save Messel pit} Munich

AN appeal to the United Nations has now been issued by West German palaeontologists in a last-ditch attempt to save the fossil-rich Messel pit. The pit, near Darmstadt, will become a rubbish dump this autumn under a ruling earlier this year of the South Hesse regional council, which has set aside 15 years of attempts by researchers to have the pit left alone.

The Messel pit, first excavated in the nineteenth century, is one of the richest known sources of well-preserved Eocene fossils in the world. Fifty million years ago, the area was a lake, in which dead animals and plants of the age were preserved in oxygen-poor sediments. The evolution of these sediments into oil shale led to the remarkable preservation of the fossils. Among the finds are a very rare, almost complete skeleton of a primordial cat-sized horse, Propalaeot herium parvulum and a large variety of bats.

Mining operations at Messel halted in 1971 when they became unprofitable. Talk of using the pit as a rubbish dump began soon afterwards. The government plans to dump up to 25 million $\mathbf{m}^{3}$ of rubbish into the 60-m-deep pit, thus solving a long-standing waste disposal problem in the Frankfurt-Darmstadt area.

Steven Dickman
Science and Culture have been quick to spot a potential money winner in the new superconductors. The agency set up a research committee in February with members drawn from the universities, government and industry to exchange information and hold symposia. Financial support for the committee's activities is provided by a small membership fee ( $¥ 200,000)$ from participant companies (which now number about 130 ). MITI also set up a similar "study group" which will publish a report on its meetings in September, and the Ministry of Education took the extraordinary step of extending a grant for research on oxide superconductors by advancing an extra $¥ 160$ million (about \$1 million) (see Nature, 327, 356; 1987).

Now, with the season for budget applications little over a month away, MITI and the Science and Technology Agency have revealed their plans for fiscal year 1988. The agency proposes establishing a "multi-core project" to be carried out by four of its institutes: the National Research Institute for Metals, the National Institute for Research in Inorganic Materials, the Japan Atomic Energy Research Institute and the Institute for Physical and Chemical Research.

Each institute will form a research team in a particular field and these research 'cores' will interact by holding regular meetings, according to Masahiro Kawasaki, director of the agency's Research and Development Bureau.

Kawasaki says the agency will apply for $¥ 10,000-15,000$ million $\quad(\$ 70-100$ million) to set up facilities for superconductor research in the National Research Institute for Metals and National Institute for Research in Inorganic Materials in fiscal year 1988. Such a proposed level of funding is extraordinary as the total budget for these two institutes is normally only about $¥ 11,000$ million, according to Kawasaki.

MITI's plans for government-funded research are more modest. The ministry intends to incorporate development of ceramic thin films and Josephson junction devices into an existing project. The "new functional devices" project aims at creating such things as three-dimensional integrated circuits and biochips and is supported with funds of about $¥ 1,400$ million in this fiscal year.

MITI also hopes to take advantage of the present interest in superconductors to win $¥ 2,000-3,000$ million in the next fiscal year to develop a $70,000-\mathrm{kW}$ superconducting generator as part of the Moonlight Project. Moonlight was created in 1978 during the last oil crisis to cut energy consumption through the development of a host of power-saving devices, including giant batteries for night storage of electricity, fuel cells and a Stirling cycle engine. Mitsubishi Electric Corporation and Fuji Electric Co. have already built a $30,000-\mathrm{kW}$ superconducting generator under a different MITI programme which ended about three years ago, and Mitsubishi, Hitachi and Toshiba are expected to participate in development of the new generator which will employ niobium-titanium superconducting wire in the armature and a conventional magnet, according to Yasuo Hashimoto, manager of the planning department of Mitsubishi's Materials and Electronic Devices Laboratory. One hundred million yen $(\$ 700,000)$ has been set aside in this year's budget for a feasibility study of the generator, development of which is expected to take about seven years.

But MITI's most ambitious plan is to establish a non-profit foundation, the "international superconductor industry and technology promotion centre", with funds from the private sector. MITI hopes 80 to 100 companies, including nine electric power companies and electronics, ceramic and cable manufacturers, will join the centre which could be set up as early as this autumn. The nine power companies already run a research cooperative, the Central Institute of the Electric Power Industry, which funnels funds to companies developing superconducting wire. And, according to Rizaburo Nezu of MITI's Agency of Industrial Science and Technology, this institute will play a role in establishing the new centre.

With support from 20-30 key companies, MITI hopes to set up a research institute within the centre which would hold international symposiums and exchange researchers with the US and Europe.

The Science and Technology Agency is also calling for international collaboration, and the agency's superconductor committee, which is open to foreign membership, is expected soon to be converted into a non-profit foundation and will hold its first international symposium towards the end of this year.

The Ministry of Education has yet to show its cards. Although the Ministry does not command the 'big science' budgets of the Science and Technology Agency and MITI, it does wield considerable control over research in the universities through the distribution of grants, and few researchers would risk accepting money from MITI or the agency for fear of being cut off from this source of funds. It is widely expected that Professor Shoji Tanaka, leader of the Tokyo University superconductor research group, will get about $\$ 1$ million when awards for this fiscal year are announced on 28 July.

David Swinbanks 